Eskişehir Osmangazi Üniversitesi

Sosyal Bilimler Dergisi

Haziran 2020, 21(1), 59-84

DOI: 10.17494/ogusbd.763397

\title{
Öz Yeterliğin Bilinçli Farkındalık ve Benlik Saygısına Etkisi ${ }^{*}$
}

\author{
Gizem YILDIRIM, Gaye ATILLA** \\ Öz Yeterliğin Bilinçli Farkındalık ve Benlik Saygısına Etkisi \\ The Effect Of Self-Efficacy On Mindfulness and Self- \\ Esteem
}

\section{Özet}

Bu çalışmada üniversite öğrencilerin öz yeterliklerinin bilinçli farkındalık ve benlik saygıları üzerindeki etkisini araştırmak hedeflenmiştir. Araştırma Süleyman Demirel Üniversitesi "Örgütsel Davranış" dersini alan öğrencileri kapsamaktadır. Araştırma 124 öğrencinin katılımı ile gerçekleştirilmiştir. Çalışmada bilinçli farkındalık, öz yeterlik ve benlik saygısı kavramları ilgili literatür çerçevesinde araştııımış, ardından ilişkilere yönelik hipotezler geliştirilmiştir. Bu değişkenler arasındaki ilişkiyi belirlemek için yapılan korelasyon analiz sonuçlarınagöre; bilinçli farkındalıkile öz yeterlik arasında zayıfve negatif bir korelasyon, benlik saygısı ile orta şiddette negatif bir korelasyon olduğu tespit edilmiştir. Öz yeterlik ile benlik saygısı arasında zayıf ve pozitif bir korelasyon olduğu saptanmıştır. Öz yeterliğin bilinçli farkındalık ve benlik saygısı üzerindeki etkisini saptamak için yapılan regresyon analizi sonucunda öz yeterliğin, benlik saygısı ve bilinçli farkındalık üzerinde anlamlı bir etkiye sahip olduğu gözlemlenmiştir.

Anahtar Kelimeler: Bilinçli Farkındalık, Öz Yeterlik, Benlik Saygısı.

Makale Türü: Araştırma
Abstract

In this study, it was aimed to investigate the effect of university students' self-efficacy on mindfulness and self-esteem. The research includes students who taking the "Organizational Behavior" course at Süleyman Demirel University. The research was carried out with the participation of 124 students. In the study, the concepts of mindfulness, self-efficacy and self-esteem were researched within the framework of the related literature, and then hypotheses were developed for relationships. According to the correlation analysis results made to determine the relationship between these variables; a weak and negative correlation between mindfulness and self-efficacy, a negative correlation with self-esteem and moderate severity. A weak and positive correlation was found between self-efficacy and selfesteem. As a result of regression analysis to determine the effect of self-efficacy on mindfulness and self-esteem, it has been observed that self-efficacy has a significant effect on self-esteem and mindfulness.

Keywords: Mindfulness, Self-Efficacy, Self-Esteem.

\section{Giriş}

Farkındalık, dikkatin anlık yaşantılara odaklanmasını ve içsel tecrübelerin gözlemlenmesini içeren bir zihin ve beden pratiğidir. Farkındalık çok eski bir Budist uygulamasıdır ve kim olduğumuzu incelemektedir. Dünyayı ve dünyadaki yerimizi nasıl gördüğümüzü sorgulamaktır. Bilinçli farkındalık hem farkındalık hem de bilinçliliği içeren, kabul, yargııızlık ve şimdiki ana odaklanmayı temel alan

*B Bu çalışma, Süleyman Demirel Üniversitesi Sosyal Bilimler Enstitüsü, İşletme Anabilimdalı İşletme Yüksek Lisansı programında yürütülen "Öz Yeterlik Algısının Bilinçli Farkındalık ve Benlik Saygısı Düzeylerine Etkisi" adlı tez çalışmasından adapte edilerek hazırlanmıştır.

** Gizem YILDIRIM, Süleyman Demirel Üniversitesi, İşletme ABD, yldrmgizeem@gmail.com, orcid.org / 0000-00020601-7036, Gaye ATILLA, Doç. Dr., Süleyman Demirel Üniversitesi, İşletme, gayeatilla@sdu.edu.tr, orcid.org / 00000003-1421-917X. 
derin bir farkındalık halidir. Bilinçli farkındalık halinde birey dikkatinin nereye yöneldiğinin ve zihninin ne ile meşgul olduğunun farkındadır (Cengiz vd., 2016: 1321).

Öz yeterlik, "bireyin kendisinden beklenen durumları yönetmesini sağlayacak yeteneklere olan inancı" olarak tanımlanmaktadır (Bandura, 1997: 2). Bu bağlamda bireylerin yeterlilik beklentilerine dair algılamaları, yani öz yeterlikleri, onların eyleme geçmelerini ve sorunlarla mücadele gayretlerini etkilemektedir (Basım vd., 2008:122). Öz yeterlik inancını belirleyen dört temel kaynak bulunmaktadır. Bu kaynaklar; kişilerin kendi öğrenme tecrübeleri ile elde ettiği bilgiler, başka kişilerin başarılı ya da başarısız uygulamalarına ilişkin gözlemler, başarabileceğine ya da başaramayacağına dair toplumun etkisi ve görevi başarma ya da başarısız olma beklentisine ilişkin psikolojik durumdur (Bandura, 1994: 71).

Benlik kavramı, bireyin kendi kişiliğine dair algılayabildiği tarafını, yani kişinin bilinçli bir biçimde kabiliyetleri, sınırları, gayeleri, değer yargıları, kimliği, fiziksel görünüşü gibi kendi var oluşu olarak nitelendirebildikleri hakkındaki görüşlerinin, tutumlarının ve inançlarının hepsini içermektedir. Yani kişinin kendisini tanıma ve değerlendirme tarzıdır. Benlik saygısı ise, kendini kabullenme, kendine değer verme, onaylama, saygı duyma; kendi değerine dair değerlendirmesidir (Yıldız ve Çapar, 2010: 105).

Bu araştırmanın amacı öğrencilerin öz yeterliklerinin benlik saygısı ve bilinçli farkındalıkları üzerindeki etkisini ortaya çıkarmaktır. Bu bağlamda öncelikle bilinçli farkındalık, öz yeterlik ve benlik saygısı kavramları açıklanarak aralarındaki ilişkiler kurgulanmış, daha sonra ise Süleyman Demirel Üniversitesi'nde öğrenim gören ve Örgütsel Davranış dersini alan öğrencilerden seçilen uygun bir örneklem üzerinde gerçekleştirilen bir araştırma ile faktörler arasındaki ilişkilerin ortaya çıkarılması amaçlanmıştır. Örgütsel davranışın amacl; örgütsel etkililiği sağlamak, bireylerin edinimlerini yükseltmek, işten ve çevreden alacağı doyumu arttıracak davranışsal önermeler geliştirmektir. Bu amaca ulaşmak için bireylerin bilişsel, devinimsel ve duygusal davranışlarını, örgüte uyumu sağlamalarının yollarını, takım içindeki çalışmalarını, bireylerin davranışlarını etkileyen unsurları araştırmaktadır. Örgütsel Davranış dersini alan öğrencilere bu yönde eğitimler verilmektedir. Bu sayede öğrencilerin davranış ve tutumlarının pozitif anlamda gelişmesi ve değişmesi amaçlanmaktadır. Bu nedenle ele alınan değişkenlerin arasındaki ilişkiyi açıklayabilmek adına örneklem, bu dersi alan öğrencilerden oluşmaktadır.

Yapılan literatür çalışması ve incelemeler sonucunda bilinçli farkındalık ile öz yeterlik ve öz yeterlik ile benlik saygısı arasındaki ilişkileri belirlemeye çalışan birçok çalışma mevcuttur. Ancak Türkçe literatürde, öz yeterliğin bu iki değişken üzerindeki etkilerini inceleyen bir çalışmaya rastlanamadığından, bu çalışmanın öğrencilerin öz yeterlik davranışları konusuna farklı bir bakış açısı kazandırması ve elde edilecek sonuçların konuya ışık tutacağı değerlendirilmektedir. 


\section{Bilinçli Farkındalık}

Farkındalık bireyin kendi düşünce, his ve fiziksel bedenini inceleyerek, "Şu anda ne yaşıyorum?” sorusunu kendisine sorarak cevaplamasıdır. Bu bağlamda farkındalık, şu anda ne düşünüldüğü, ne hissedildiği, duyu organlarıyla ne algılandığı ve bedende nerelerin ne kadar fark edildiğine odaklanılması aracılığıyla dikkatin "o an"da olması anlamına gelmektedir (Yelkenci, 2019: 18). Bilinçli farkındalık teriminin kökeni 2500 yıl öncesinin Budist psikoloji dili olan Pali dilindeki "Sati" kelimesidir. Sati farkındalığı, dikkati ve hatırlamayı ifade etmekte (Germer, 2004: 25) ve bu kavramları bünyesinde barındırmaktadır. Dikkat ve bilinçlilik yaşanılan ana, hatırlama ise yaşanılan anda dikkat ve bilinçliliğin hatırlanmasına ilişkindir. Bu nedenle bilinçli farkındalık anda gerçekleşen duygusal, bilişsel ve fiziksel deneyimlerin dikkatle bilincinde olmak ve bunu unutmamak şeklinde açıklanmaktadır (Siegel vd. 2009: 2). Brown ve Ryan’a (2003: 822) göre bilinçli farkındalık, içinde yaşanılan zaman diliminde oluşan olayların farkında olma durumu ve dikkatliliktir. Acıyı azaltan bütün tecrübelerle ilişkide olmanın ve olumlu kişisel dönüşüm için adım atmanın basit bir yolu olan (Siegel vd. 2009: 10) ve duyguları düzenlemede etkili olan bu kavram, kişilerin kendilerinin ve başkalarının duygularını düzgün bir şekilde algılamalarına ve düzenlemelerine yardımcı olmaktadır. Bilinçli farkındalığın bünyesinde kendini düzenleme, duygusal zekânın duyguları yönetmesi de bulunmaktadır (Schutte ve Malouff, 2011: 1117).

Bilinçli farkındalığa sahip olan kişi mutlu, rahat, hazır ve uyanıktır. Zihni algılayabilmenin ve düşünceleri dinginleştirmenin yolu hislerin ve algıların farkında olmayı tecrübe etmekten geçmektedir. Mühim olan bir düşüncede takılı kalmak ya da onu göz ardı etmek değil, o düşüncenin bilincinde olmaktır. Bilinçli farkındalık sayesinde bireyin ustalaşarak kendisini düzeltmesi ve geliştirmesi mümkün olmaktadır. Günlük yaşamın içinde dağılan zihni aydınlatmak ve tekrar toparlayarak yaşanılan her anı fark etmek için bütünlüğü sağlamak, bilinçli farkındalığın bir mucizesidir. Bilinçli farkındalığa sahip olan kişi mutlu, rahat, hazır ve uyanıktır. Zihni algılayabilmenin ve düşünceleri dinginleştirmenin yolu hislerin ve algıların farkında olmayı tecrübe etmekten geçmektedir. Mühim olan bir düşüncede takılı kalmak ya da onu göz ardı etmek değil, o düşüncenin bilincinde olmaktır. Bilinçli farkındalık sayesinde bireyin ustalaşarak kendisini düzeltmesi ve geliştirmesi mümkün olmaktadır. Günlük yaşamın içinde dağılan zihni aydınlatmak ve tekrar toparlayarak yaşanılan her anı fark etmek için bütünlüğü sağlamak, bilinçli farkındalığın bir mucizesidir (Hanh, 1987: 60).

Germer'e (2005: 9) göre, bilinçli farkındalık anlarının ortak özellikleri bulunmaktadır; kavramsal değildir; bilinçli farkındalık somutlaştııımıştır, sezgisel farkındalık ve düşünce süreçlerinden uzaklaştırımışır. Âna odaklıdır; farkındalık her zaman şimdiki zamandadır. Yargılayıı değildir; yaşanılanlar sevilmezse farkındalık özgürce gerçekleşemez. Amaçlıdır, katıımcı gözlemini gerektirir; bilinçli farkındalık, şahit olmaktan bağımsız değildir. Sözel değildir; bilinçli farkındalık tecrübesi kelimelerle yakalanamaz, çünkü farkındalık zihinlerde ortaya çıkmadan önce gerçekleşmektedir. Keşfe dayalıdır, özgürleştiricidir; bilinçli farkındalığın her anı, şartlara bağlı gerçekleşen dertlerin özgürlüğü ve rahatsızlığı etrafında boşluk sağlar. 


\section{3. Öz Yeterlik}

Öz yeterlik, bireylerin hayatlarını etkileyen olaylar üzerinde etkili olabilecek performansı oluşturmaları için gereken davranışı başlatıp, bir sonuç alana kadar devam edebileceklerine olan inançları şeklinde tanımlanmaktadır (Bandura, 1994: 2). Vardarlı (2005: 2)’ya göre öz yeterlik, benlik sisteminin durgun bir özelliği ya da belirleyicisi olmayıp, kişinin işi yapabilme yeterliğinin gerçekleştirdiği işlerdeki başarılarının, güdülerinin ve öz düzenlenme mekanizmaları gibi benlik sistemini oluşturan diğer öğelerin bileşkesinden oluşan dinamik bir yönü olmaktadır.

Schwarzer (1994) de bireyin yeni durumları aktif bir biçimde yönetmesine ve sayısı alandaki olumsuzluklarla yüz yüze geldiğinde çaba sarf etmesine yardımcı olduğunu vurgulamaktadır (Aşık, 2019: 12). Öz yeterlik, kişilerin hayatlarındaki olayları kontrol edebilmek için gerekli olan bilişsel, güdüsel, davranışsal kaynaklara ve gerektiğinde bu kaynakları harekete geçirebilecek kapasiteye sahip olduklarına dair inançlarıdır. Bu bağlamda; başlangıçta durum ya da görev bağımlı bir kapasiteye ilişkin iç inanca gösterge olarak kullanılan öz yeterlik kavramı; daha sonra kişilerin hayatındaki olayların üstesinden gelebilecek kapasiteye sahip oldukları yolundaki genellenmiş bir inanç olarak ifade edilmeye de başlanmıştır (Demir, 2013: 90).

Öz yeterlik bireyin sadece ne yapması gerektiğini bilmesi ve yapması için motive olması anlamına gelmemektedir. Dahası öz yeterlik beklentisi, kişinin davranış birikiminde sahip olduğu veya olmadığı sabit bir beceri ve tek başına davranışın belirleyicisi de değildir. Eğer kişilerin üst düzey becerileri eksikse, beklenti tek başına beklenen başarımın oluşmasında yeterli değildir. Bununla beraber, elverişli yetenekler ve yeterli teşvikler olduğunda, öz yeterlik beklentisi, kişilerin ne kadar gayret sarf edeceklerini, stres faktörleriyle başa çıkma çabalarını ve faaliyet tercihlerini ne denli sürdüreceklerini belirleyen önemli bir unsurdur. Özetle öz yeterlik, bireyin sahip olduğu yetenek sayısıyla değil, çeşitli koşullar altında sahip olduğu şeylerle neler yapabileceğine olan inancıyla alakalıdır (Bandura, 1997: 138).

Öz yeterlik algısı yüksek olan bireyler daha açık görüşlüdür ve sorunlara farklı alternatifleri düşünerek yaklaşarak çözüme daha rahat ulaşabilmektedirler. Öz yeterliği düşük olan kişiler kendilerini kaygılandıran etkinliklere katılmaktan kaçınmakta veya yalnızca başarılı olacaklarını düşündükleri etkinlikleri seçmektedirler. Diğer açıdan bakıldığında ise öz yeterliği yüksek olan bireyler etkinliklere daha istekli katılmakta ve daha iyi çalışabilmektedirler(Atalay vd., 2017a: 1805).

Düşük öz yeterlik inancına sahip bireyler, kişisel tehdit olarak algıladıkları zorlu görevlerden kaçma eğiliminde olmaktadırlar. Bu bireylerin daha küçük amaçları vardır ve bu amaçlara duydukları bağlılıkları zayıftır. Zorlu görevlerle karşılan bireyler, nasıl başarılı bir performans sergilemeleri gerektiğine yoğunlaşmaktan ziyade, kişisel eksikliklerine, karşılaşacakları engellere ve diğer tüm olumsuz sonuçlara odaklanmaktadırlar (Bandura, 1994: 2). Dolayısıyla öz yeterliği düşük olan bireyler, zorlu görevleri genellikle korku merceği aracilığıyla görmektedirler. Düşük öz yeterlik bir döngü haline gelmekte ve beceriye dair inanç eksikliği, eylem eksikliğini yaratmaktadır. Eylem 
eksikliği, bireyin kendisinden şüphe duymasına sebep olmaktadır. Kendi becerilerinden şüphe duyanlar da stres ve sıkıntıyı daha üst seviyede yaşamaktadırlar (Singh ve Udainiya, 2009: 228).

\section{Benlik Saygısı}

Benlik, kişinin kendine dair farkında olduğu algılamalarının örgütlenmiş bir biçimi olarak tanımlamaktadır. Birey, çevresiyle etkileşim içinde donanımlarının farkına varmakta, olumlu ya da olumsuz değerlendirmelerle amaç ve hedefler geliştirmektedir. Dolayısıyla benlik, kişinin yaşantıları aracılığıyla elde ettiği ve farkına vardığı özelliklerinin algısal bir şeması olmaktadır (Rogers, 1951: 47). Cooley (1902) benliği, farklı bir yaklaşımla ele almakta, ona göre bireyler gelişim süreci içinde diğerlerinin onları nasıl gördüklerine dair bir bilinç geliştirmektedirler. Zamanla diğer bireylerin kendileri hakkındaki görüşlerini zihinlerinde canlandırmaya başlamaktadırlar. Cooley'in "ayna benlik metaforu", benlik kavramını, sosyal etkileşimin bir unsuru olarak ortaya koyması bakımından oldukça önemlidir. Bu metafora göre benlik kavramı, diğer bireylerin tepkilerinin bir yansıması olarak oluşmaktadır. Bireyler, çevresindeki kişilerin görünümünü ve davranışlarını değerlendirirken, asıında başkalarının sahip olduğu yargıların hayali bir yansımasını görmektedir. Bireyin benlik algısı da söz konusu yargılara dair küçük düşme veya gurur gibi hisleri ile oluşmaktadır (Soğukpınar, 2014: 14).

Benlik saygısı, bireyin sahip olduğu yetenek ve kapasiteleri kabullenmesi ve kendine değer vermesine dair bir değerlendirmeyi içermektedir (Mckay ve Fanning, 2000: 1-2). Rosenberg (1965: 6) bu kavramı kişinin kendisine karşı pozitif ya da negatif tutumu şeklinde açıklamakta ve bu kavramın yüksek ve düşük benlik saygısı olarak iki boyutunu olduğunu ifade etmektedir. Yüksek benlik saygısına sahip kişiler, kendilerini saygıdeğer ve değerli hissetmekte, fakat bu kendini üstün görme anlamına gelmemektedir. Düşük benlik saygısına sahip kişiler ise kendilerinden memnun olmayıp, kendilerini reddetmektedirler.

Benlik saygısı sosyal toplumda önemli bir ihtiyaçtır. Ebeveyn ve çocuk arasında, işçiler ve işverenler arasında, öğretmen ve öğrenci arasında, şehirlerarasında, kısacası her yerde bireyler benlik saygısını korumak için çaba sarf etmektedir. Sayısız kişi, toplumda her düzeyde yetersizlik duygusunu telafi edebilmek adına hayali ya da gerçek olarak gayret göstermektedir. Seçkin psikologlardan biri olan Abraham Maslow, ihtiyaçlar hiyerarşisini ileri sürmüştür. Hiyerarşinin alt kısımlarında kişisel ihtiyaçlar yer alırken, hiyerarşinin üst kısımlarında daha entelektüel ve sosyal intiyaçlar yer almaktadır. İnsanların temel fizyolojik intiyaçları karşılanmadıkça benlik saygısı gibi sosyal ihtiyaçların karşılanması beklenemez. Üzücü bir gerçek şudur ki, kişiler yetersizlik duygularını tamamen kabul etmektedir. Bireyler kendilerini yetersiz görmekte ve diğerleri kadar değerli olmadıklarına karar vermektedirler. Okuryazarlık yeteneği gerektirmeyen işlerde çalışmayı tercih etmektedirler ve bu genellikle bireyin akademik eğilimli olmamasıyla alakalı olmamaktadır. Birey eğer üst düzey bir zekâ seviyesine sahip ise kabul konusunda sıkıntı yaşamakta ve onun için yaptığı iş sıkıcı ve belki de bayağı olduğu düşüncesiyle katlanılmaz olabilmektedir (Lawrence, 2000: 5-6).

Yüksek benlik saygısına sahip bireyler, sağlıklı bir görünümün olmamasını görmezden gelmektedir. Bireyin gerçekçi benlik eksikliklerini fark etmesini kapsamakta, fakat bunları sert bir biçimde eleştirmemektedir. Benlik saygısı, bireyin kendisini olumlu şekilde değerlendirmesi ve 
kendisinin güçlü yönleri hakkında iyi hissetmesidir. Bu noktada, bireyin herhangi bir biçimde farklı olma gibi bir isteği bulunmamaktadır. Aksine, kendisini bağışlayan, kendine güvenen ve kendini iyileştirmeye çalışan bir görünümdedir. Benlik saygısı düşük bireyler ise, genellikle yapay olumlu bir benlik tavrı göstermeye gayret etmektedir. Kendisini diğer bireylere kanıtlamak için umutsuz bir gaye içinde bulunmakta ya da reddedileceği düşüncesi ile korkmaktadır. Başka insanlarla temas etmekten endişe etmekte ve kendi içine çekilebilmekte ve kendisiyle de az gurur duymaktadır (Pope vd., 1988: 2).

\section{Bilinçli Farkındalık, Öz Yeterlik ve Benlik Saygısı İe illgili Çalışmalar}

Araştırmanın bu bölümünde bilinçli farkındalık, öz yeterlik ve benlik saygısı ile ilgili çalışma örnekleri sunulmuştur.

\subsection{Bilinçli Farkındalık ile İlgili Çalışmalar}

Brown ve Ryan (2003) bilinçli farkındalık ve psikolojik iyi oluş arasındaki ilişkiyi incelemek için 327 lisans öğrencisi üzerine bir araştırma gerçekleştirmişlerdir. Çalışma sonucunda araştırmaya katılan öğrencilerin bilinçli farkındalık düzeyleri ile duygusal düzensizlik, kaygı, depresyon düzeyleri arasında negatif yönlü bir ilişki, yaşam doyumu, benlik saygısı, iyimserlik, kendini gerçekleştirme, özerklik ve yeterlilik düzeyleri arasında ise pozitif yönlü bir ilişkinin varlığını ortaya koymuşlardır.

Palmer ve Rodger (2009) 135 üniversite öğrencisi üzerinde bilinçli farkındalık ile algılanan stres ve baş etme stillerinin ilişkisi üzerine bir araştırma gerçekleştirmişlerdir. Araştırma sonucunda katılımcıların bilinçli farkındalık düzeylerinin mantıksal baş etme ile pozitif yönlü bir ilişkiye, algılanan stres, duygusal ve kaçınmacı baş etme ile de negatif yönlü bir ilişkiye sahip olduğu bildirilmiştir.

Rasmussen ve Pidgeon (2010) 205 üniversite öğrencisi üzerinde bilinçli farkındalık, benlik saygıSı ve sosyal kaygı arasındaki ilişki konulu bir araştırma gerçekleştirmişlerdir. Araştırma sonucunda bilinçli farkındalığın benlik saygısı ile pozitif, sosyal kaygıyla ise negatif yönlü ilişkiye sahip olduğu bildirilmiştir.

Rice vd. (2013) Amerikan ordusunda görev yapan 30 asker üzerinde bilinçli farkındalık ve psikolojik dayanıkılık ilişkisi konulu bir araştırma gerçekleştirmiştir. Sonuç olarak katılımcıların bilinçli farkındalık düzeyleri ve psikolojik dayanıklıık düzeyleri arasında pozitif yönlü bir ilişkinin varlığı gözlemlenmiştir.

Çelik ve Çetin (2014) 321 üniversite öğrencisi üzerinde çatışma çözme yaklaşımlarında bilinçli farkındalık ve öz bilincin rolü konulu bir araştırma yapmışlardır. Araştırma sonucunda bilinçli farkındalığın yapıcı ve olumlu çatışma çözme süreçleri üzerinde etkili olduğu bildirilmiştir.

Verilen çalışma örneklerinden de görüldüğü üzere bilinçli farkındalığın benlik saygısı, yaşam doyumu, kendini geliştirme, yeterlilik, empati, mantıksal baş etme, psikolojik dayanıklılık gibi değişkenlerle pozitif bir ilişkisinin olduğu gözlemlenmiştir. Bu bağlamda bilinçli farkındalığı yüksek bireylerin kendilerini daha iyi geliştirebildiği, benlik saygısı seviyelerinin daha yüksek olduğu ve yaşamdan aldıkları doyumun daha üst seviyede olduğu yorumu yapılabilmektedir. 


\section{2. Öz Yeterlik ile ilgili Çalışmalar}

Joo vd. (2000) tarafından Seul'de ortaokul ikinci sınıfta karma eğitim veren 152 eğitimci üzerinde yapılan çalışmada akademik öz yeterlikle akademik başarı arasındaki ilişkiyi incelemektedir. Çalışma sonuçlarına göre standardize edilmiş başarı testi ile akademik öz yeterlik arasında pozitif yönde anlamlı ilişki bulunmakta ve standardize edilmiş başarı testi öğrencilerin akademik özyeterliklerinin yordadığı da tespit edilmiştir.

Tang vd.'nin (2004) çalışmasında psikolojik danışman adaylarının psikolojik danışma öz yeterliği ile mesleki deneyimleri ve alınan psikolojik danışma kurs sayısı arasında pozitif yönde anlamlı ilişki bulunmuştur.

Acat vd. (2011) ilköğretim okul müdürlerinin mevzuatta belirtilen görevlere dair öz yeterliklerini belirlemek maksadıyla bir çalışma yapmıştır. Araştırmaya Ordu ilinde görev yapan 180 ilkokul müdürü katılııştır. Araştırma sonucunda, okul müdürlerinin mevzuat görevlerini oluşturan okul işletmesi, eğitim-öğretim işleri, öğrenci işleri ve personel işleri boyutlarında öz yeterlik düzeylerinin yüksek olduğu ve kıdem arttıkça öz yeterlik düzeyinin arttığı saptanmıştır.

Ünlü (2014) ilişkisel tarama modelinde 1010 ortaokul öğrencisi ile yürütttüğü çalışmada ortaokul öğrencilerinin öz yeterlik düzeyleri ile Türkçe dersine yönelik tutumları arasında pozitif yönde bir ilişki bulunduğunu gözlemlemiştir.

Taşgın (2015) çalışmasında Türkçe öğretmeni adaylarııın dinleme, konuşma, okuma ve yazma öz yeterlikleri ile öğrenme stillerini incelemeyi amaçlamış ve araştırma sonuçlarına göre cinsiyet ve öğrenim gördükleri sınıf derecesi değişkenlerine dinleme, konuşma, okuma ve yazma öz yeterlikleri arasında anlamlı fark yarattığı saptanmıştır. Öğrenim gördükleri lise değişkenine göre dinleme, konuşma, okuma ve yazma öz yeterlikleri arasında anlamlı fark yaratmadığı tespit edilmiştir.

Öz yeterlik ile ilgili verilmiş olan örnek çalışmalarda, öz yeterlik algısının akademik başarı, kendini düzenleme, iyimserlik, öğrenci başarısı, azim, motivasyon, kendini geliştirme gibi değişkenlerle pozitif bir ilişkisini olduğu gözlemlenmiştir. Elde edilen bu ilişkiler doğrultusunda öz yeterliği yüksek olan bireylerin başarı seviyesinin, kendini geliştirebilme duygusunun yüksek olduğu sonuçlarına ulaşılabilmektedir.

\subsection{Benlik Saygısı İle ilgili Çalışmalar}

Brennan (1985) öğrenci aktivitelerine katılmanın ergenlerin benlik saygısına etkisini saptamak için 202 üniversite öğrencisi ile yürüttüğü çalışmasında, aktivitelere yoğun katılımın öğrencilerin benlik saygılarını yükselttiğini tespit etmiştir.

Long (1986) araştırmasında, aile yapısının ve anne babanın anlaşmazlı̆ııın üniversite birinci sınıfta öğrenim gören kız öğrencilerin benlik saygısı üzerindeki etkilerini çalışmıştır. Araştırma sonuçlarına göre, anne-babaların mutluluğu ile gençlerin benlik saygıları arasında anlamlı bir ilişki olduğu görülmüş, fakat aile yapısı ile ilişkili olmadığı tespit edilmiştir. 
Maşrabacı (1994) çalışmasında 347 üniversite öğrencisinin kişisel, psikolojik, sosyal ve ailesel bazı değişkenlerle benlik saygıları arasındaki ilişkiler incelenmiştir. Araştırma sonuçlarına göre, aylık gelirin yeterli bulunması, depresyon düzeyinde azalma, fiziki görünümlerinden hoşnut olmak, eleştiriye duyarlılığın azalması durumunda benlik saygısının yükseldiği görülmüştür.

Şahin (1994) yetiştirme yurtlarında kalan 15-18 yaş arası 223 kız ve erkek öğrencinin benlik saygılarını incelemiştir. Çalışma bulgularına göre, okuyan öğrencilerin benlik saygıları sanat öğrenenlere göre, arkadaş edinme güçlüğü olmayan gençlerin benlik saygıları diğerlerine göre, okulda ve iş yerinde kendini başarılı olarak algılayan öğrencilerin benlik saygıları, başarısız olarak algılayanlara göre daha yüksek bulunmuştur.

Erbil ve Bostan (2004)'ın 65 ebe ve 109 hemşire olmak üzere toplam 174 katılımcı üzerinde gerçekleştirdikleri çalışmanın amacl; ebe ve hemşirelerde iş doyumu ve benlik saygısı arasındaki ilişkiyi incelemektir. Yapılan analizlerde, iş doyumunun alt boyutları ile benlik saygısı arasındaki ilişki değerlendirilmiştir. Elde edilen sonuçlara göre, içsel doyum ve genel iş doyumu ile benlik saygısı arasında pozitif ilişki bulunmuştur.

Kahriman'ın (2005) Karadeniz Teknik Üniversitesi Trabzon Sağlık Yüksekokulu’nda öğrenim gören 441 öğrencinin benlik saygıları ile atılganlık düzeylerini bazı değişkenler açısından incelemeyi amaçlayan çalışmasında; benlik saygısı ile atılganlık düzeyi arasında pozitif bir ilişkinin bulunduğu, benlik saygısı düzeyi yükseldikçe, atılganlık düzeyinin de yükseldiği belirlenmiştir.

Yukarıda benlik saygısı ile ilgili sunulmuş örnek çalışmalarda, benlik saygısının problem çözme becerisi, içsel doyum, karar verme, atılganlık düzeyi ve yaşam tatmini gibi değişkenlerle pozitif bir ilişkisinin olduğu görülmüştür. Sonuç itibariyle benlik saygısı yüksek olan bireylerde içsel doyumun yüksek olduğu, daha kolay karar verebildiği, herhangi bir problemle karşılaştığında kolayca çözüme ulaşabildiği tespit edilmiştir.

\subsection{Bilinçli Farkındalık ve Öz Yeterlik ile ilgili Çalışmalar}

Luberto vd. (2014) 180 lisans öğrencisinin, öz yeterlik, bilinçli farkındalık ve duygu düzenleme durumları zorlukları arasındaki ilişkileri incelemiştir. Araştırma sonuçlarına göre, bilinçli farkındalık ile hareket etmenin öz yeterlik ile ilişkili olduğunu ve duygu düzenleme zorlukları arasındaki ilişkiye kısmen aracılık ettiğini gözlemlemiştir.

Hanley vd. (2015) 243 üniversite öğrencisinin farkındalık, olumlu yeniden değerlendirme ve öz yeterlik inançları arasındaki ilişkileri ele almıştır. Elde edilen sonuçlara göre, farkındalık ve olumlu yeniden değerlendirme arasında bir ilişki olduğu görülmüş ve farkındalığın yanı sıra olumlu yeniden değerlendirmenin, öz yeterlikle olumlu bir şekilde ilişkili olduğu saptanmıştır.

Fallah (2016) 295 İran İngilizcesi öğrenen öğrencinin, öz yeterlik, bilinçli farkındalık ve yaşadığı yabancı dil kaygısı arasındaki ilişkiyi saptamaya çalışmıştır. Öz yeterliğin, bilinçli farkındalık ve dil kaygısı arasındaki ilişkide aracılık etme kapasitesini incelemiştir. Analiz sonuçları, bilinçli farkındalığı yüksek olanların öz yeterliklerinin yüksek olduğunu ve dil kaygılarının düşük seviyede olduğunu 
göstermiştir. Öz yeterliğin bilinçli farkındalık ve dil öğrenme kaygısı arasında kısmen aracılık edebileceği saptanmıştır.

Atalay vd. (2017b) 11-13 yaş aralığındaki beşinci, altıncı ve yedinci sınıf öğrencilerinin matematik kaygılarını azaltmak, öz yeterliklerini artırmak ve matematik dersine karşı olan tutumlarını olumlu yönde geliştirmek amacıyla hazırlanmış olan bilinçli-farkındalık temelli psiko-eğitim programının etkililiğini test etmek amacıyla 713 katılımcı üzerinden bir çalışma yürütmüştür. Yapılan ön test- son test karşılaştırmaları sonucunda, deney grubunun bilinçli farkındalık düzeylerinin arttığı bilinçli farkındalık-temelli öz yeterlik düzeylerinin ise hafif düzeyde arttığı tespit edilmiştir. Son test puanları açısından değerlendirildiğinde, deney grubunun matematik kaygı düzeyinin azaldığı, matematiğe yönelik olumlu tutum düzeylerinin arttığı, kontrol ve plasebo gruplarının ise matematik kaygı düzeylerinde çarpıcı bir değişim olmazken matematiğe yönelik olumlu tutum düzeylerinin arttığı tespit edilmiştir.

Bakioğlu’nun (2017) “Psikolojik Danışman Adaylarının Özyeterlikleri Ile Kültüre Duyarlılıkları, Cinsiyet Rolleri ve Bilinçli Farkındalıkları Arasındaki İlişkilerin İncelenmesi” adlı doktora tezinde 667 psikolojik danışman adayının psikolojik danışma öz yeterlikleri psikolojik danışma uygulaması öncesi aldıkları mesleki derslere ve psikolojik danışma uygulamalarına ilişkin değerlendirmelerine göre farklılaşmaktadır. Kültüre duyarlı psikolojik danışma dersi almış olanların psikolojik danışma öz yeterlikleri, dersi almayanlarınkinden anlamlı düzeyde yüksek bulunmuştur. Psikolojik danışman adaylarının cinsiyet rolleri ve bilinçli farkındalıklarının kültüre duyarlı psikolojik danışma yeterlikleri aracılığıyla psikolojik danışma öz yeterliğini yordamasındaki dolaylı etkilerin anlamlı olduğu sonucuna ulaşılmıştır.

Özkan vd.'nin (2018) çalışmasında 9-11 yaş arasında toplam 284 öğrencinin bilinçli farkındalık temelli öz yeterlik puanları cinsiyet değişkenine göre incelenmiş ve kı öğrenciler ile erkek öğrenciler arasında istatistiksel olarak anlamlı bir fark olmadığı görülmüştür. Öğrencilerin bilinçli farkındalık temelli öz yeterlik puanları okul türü değişkenine göre incelenmiş ve özel okulda öğrenim gören öğrenciler ile devlet okulunda öğrenim gören öğrenciler arasında istatistiksel olarak anlamlı bir fark olmadığı görülmüştür.

Bilinçli farkındalık ile öz yeterliğe dair verilen çalışma örneklerinde, öz yeterlik arttıkça bilinçli farkındalığın arttığı gözlemlenmiştir. Buradan yola çıkarak, ele alınan konular doğrultusunda, birinci hipotez oluşturulmuştur:

$H_{1}$ : Öz yeterliğin bilinçli farkındalık üzerinde anlamlı ve pozitif bir etkisi vardır.

\section{5. Öz Yeterlik ve Benlik Saygısı Ile ilgili Çalışmalar}

D’Amico ve Cardaci (2003) yaş ortalaması 13 olan 151 katılımcının öz yeterlik ve benlik saygısı boyutlarının skolastik başarı ile olan ilişkisini saptamaya çalışmıştır. Araştırma bulgularına göre, öz 
yeterlik ve benlik saygısı boyutları bazı ortak yönleri paylaşmakta ve özellikle benlik saygısı öz yeterlik inançlarıyla farklı büyüklüklerde ilişki göstermektedir.

Sung-Ja (2006) 172 hemşirelik öğrencisinin klinik stres, öz yeterlik ve benli saygısı arasındaki ilişkiyi tanımlaya çalışmaktadır. Öz yeterlik ve benlik saygısı düzeylerinin istatistiksel olarak anlamlı fakat düşük pozitif korelasyon gösterdiği sonucuna varılmıştır.

Altun ve Yazıcı'nın (2012) “Üstün Yetenekli Öğrencilerin Benlik Kavramları ve Akademik ÖzYeterlik İnançları: Karşılaştırmalı Bir Çalışma” sında 385 üstün yetenekli öğrencinin benlik kavramı ve akademik öz yeterlik puanları üstün olmayan her iki gruptan daha yüksek çıkmıştır.

Diseth vd. (2014) 2062 adet 6. ve 8. sınıf Norveçli öğrencinin benlik saygısı, öz yeterlik ve örtük zeka kuramları arasındaki ilişkiyi araştırmıştır. Sonuçlar benlik saygısı, öz-yeterlik ve örtük zekâ kuramları arasında pozitif ilişkiler ve varlık ile örtük zeka kuramları arasında negatif bir ilişki olduğunu göstermiştir, ancak bu ikinci ilişki 8. sınıflar arasında anlamlı olarak daha güçlüdür. 8. sınıf kızları arasında daha iyi akademik başarıya rağmen, erkeklerden daha düşük benlik saygısı, öz yeterlik ve örtük zekâ tespit edilmiştir.

Türedi'nin (2015) doktora tezinde 385 öğretmenin öz yeterlik ortalama puanları düzeylerinde kadın öğretmenler ve erkek öğretmenler açısından anlamlı bir farklılık bulunmuştur. Bu farklıık, kadın öğretmenlerin öz yeterlik düzeylerinin, erkek öğretmenlerine göre daha yüksek olmasından kaynaklandığı tespit edilmiştir.

Yiğit'in (2018) 200 kişinin katıldığı yüksek lisans tezinde cinsel öz yeterlilik ve benlik saygısı ile bilişsel çarpıtma arasında düşük düzeyli fakat istatistiksel açıdan anlamlı bir ilişki olduğu tespit edilmiştir.

Nebioğulları'nın (2019) yüksek lisans tezinde 200 ortaokul öğrencisinin benlik saygılarının, cinsiyet, annelerinin çalışma durumu ve eğitim düzeylerinden etkilenmediği ortaya konmuştur. Çocukların annelerinin sahip olduğu tepkisellik anne tutumundan (tepkisellik anne tutumu; annelerin ebeveynliklerine yönelik öz yeterlilikleri ve çocuklarına sevgi, şefkat ve tutarlı disiplin ile yaklaşmaları anlamına gelmektedir) büyük oranda etkilendiği sonucuna ulaşılmıştır.

Öz yeterlik ile benlik saygısına dair verilen çalışma örneklerinde, öz yeterlik arttıkça benlik saygısının arttığı gözlemlenmiştir. Buradan yola çıkarak, ele alınan konular doğrultusunda ikinci hipotez oluşturulmuştur:

$\mathbf{H}_{2}$ : Öz yeterliğin benlik saygısı üzerinde anlamlı ve pozitif bir etkisi vardır.

\section{Araştırmanın Yöntemi}

\subsection{Araştırmanın Amacı}

Bu araştırmanın amacı, üniversite öğrencilerinin öz yeterlik algısının bilinçli farkındalık ve benlik saygısı üzerindeki etkisini belirlemektir. Yapılan literatür çalışması ve incelemeler sonucunda bilinçli 
farkındalık ile öz yeterlik ve öz yeterlik ile benlik saygısı arasındaki ilişkileri belirlemeye çalışan birçok çalışma mevcuttur. Ancak öz yeterliğin bu iki değişken üzerindeki etkileri inceleyen bir çalışma bulunamadığından, bu çalışmanın öğrencilerin öz yeterlik davranışları konusuna farklı bir bakış açısı kazandırması ve elde edilecek sonuçların konuya ışık tutacağı değerlendirilmektedir.

Örgütsel davranışın bu değişkenlerle olan ilişkisine bakıldığında, öz yeterlik ile örgütsel davranış uygulamalarında verilen eğitim programları kişisel tecrübenin geliştirilmesi ve yeterlik kazanılması bakımından fayda sağlamakta ve öz yeterlik algısını geliştirmektir (Robbins ve Judge, 2015: 217). Bilinçli farkındalıkta kişi sadece o andadır ve şartlanma çerçevesinin dışına çıkarak olan biteni anında görmektedir (Germer, 2004: 5). Örgütsel davranış uygulamalarında bilinçli farkındalık seviyesi olumsuz duygularla başa çıkmada (Deniz vd., 2017: 18), ciddi problemlerle karşılaşıldığında probleme odaklanmak yerine problemi fark edip çözüm üretmeyi sağlamaktadır (Deniz ve Sümer 2010: 119). Benlik saygısının örgütsel davranış uygulamalarındaki etkisi ise bireylerin güç ve yetilerinin iyi bir şekilde değerlendirmesinin yapılabilmesidir (Çevik Demir, 2013: 19). Kişinin örgüt içerisinde benlik saygısını oluşturması, bireyi stres ve benzeri olumsuz duygu durumlarına karşı koruyucu kılmaktadır (Leary vd. 1995: 518). Örneklem açısından bakıldığında ise, bilinçli farkındalık ile öz yeterlik ve öz yeterlik ile benlik saygısı arasındaki ilişkileri ele alan çalışmalarda genel olarak ortaöğretim öğrencileri, öğretmenler, üstün yetenekli öğrenciler ve psikolojik danışman adayları gibi katılımcılar yer alırken bu çalışmada üniversite öğrencileri yer almaktadır. Yukarıda isimleri geçen üç konu ile ilgili ilişkiyi saptamaya çalışan Türkçe literatürde başka bir çalışmaya da rastlanamamıştır. Bu çalışmanın üniversite öğrencilerinin öz yeterlik algısının bilinçli farkındalık ve benlik saygısı davranışları üzerindeki etkisini araştıran ilk çalışma olmasının çalışmayı önemli kılacağı düşünülmektedir.

\subsection{Araştırmanın Evren ve Örneklemi}

Araştırmanın evrenini 2019-2020 güz döneminde Süleyman Demirel Üniversitesi, Örgütsel Davranış dersini alan 170 öğrenci oluşturmaktadır. Araştırmanın örneklemini ise \%95 güven aralığında 119 öğrenci oluşturmaktadır. Örgütsel Davranış dersini alan öğrencilere, duygu ve duygu durumları, kişilik ve değerler, algılama ve bireysel karar alma, motivasyon temelleri gibi örgütün verimliliğini artırmak yanında bireylerin davranışlarının da ele alındığı bir eğitim verilmektedir.

Örgütsel davranış alanına katkısı bulunan bir takım disiplinler bunmaktadır; psikoloji, sosyal psikoloji, sosyoloji ve antropoloji gibi. Bu disiplinlerden psikoloji bireysel veya mikro düzeydedir, diğerleri ise grup ve örgüt gibi makro düzeydedir. Tüm bunların temelinde yine insan ve davranışları yatmaktadır. Psikoloji, insanların davranışlarını ölçen, açıklayan bir disiplindir. Öğrenme, algı, kişilik, duygular gibi etmenlerin anlamlandıılmasıyla örgütsel davranışa katkı sağlamaktadır. Sosyal psikoloji, insanların birbirleri üzerindeki etkilerini inceler. Grup davranışları, güç ve çatışma gibi konuları açıklayarak örgütsel davranışa katkı vermektedir. Sosyoloji, insanların çevreleri ve kültürleriyle olan ilişkilerini ele alır. Örgüt içindeki grup davranışlarını işleyerek örgütsel davranışa katkıda bulunur. Antropoloji, toplumları işleyen disiplindir ve evrensel olarak farklı kültürlerdeki örgütleri inceleyerek örgütsel davranışa katkılar sunmaktadır (Robbins ve Judge, 2015: 12-14). Tüm 
bu bilgiler ışı̆̆ında örgütsel davranışın, bireylerin hem kişisel hem de yer aldığı grup ve örgüt içerisinde gösterdiği davranış ve eylemleri ile alakalı olduğu yorumu yapılabilir. Bu nedenle ele alınmış olan değişkenlerin de (öz yeterlik, bilinçli farkındalık ve benlik saygısı) bireylerin davranışlarını ve çevrelerini etkileyen unsurlar olabileceği ileri sürülebilir. Bu bağlamda verilen bu eğitim sayesinde öğrencilerin bireysel, grup ve örgüt kapsamında davranış ve tutumlarının olumlu yönde gelişmesi ve değişmesi amaçlanmaktadır. Bu nedenle ele alınan kavramların ilişkisini açıklayabilmek için örneklem, Örgütsel Davranış dersini alan öğrencilerden alınmıştır. Kolayda örneklem yönteminin kullanıldığı bu çalışma da, örneklem çerçevesinde öğrencilerden gönüllülük esasında anketleri doldurmaları istenmiş, anketleri doldurarak teslim eden öğrenci sayısı 125 olmuştur. Çalışmada uç değer incelemesi sonucunda 1 anket değerlendirme dışı bırakılmıs ve örneklem 124 öğrenci tarafindan doldurulan anketlerden oluşmuştur.

\subsection{Veri Toplama Aracı}

Araştırmada veri toplama aracı olarak anket tekniği kullanılmışıı. Araştırmada kullanılan anket formu; demografik verilere ilişkin sorular, bilinçli farkındalık, benlik saygııı ve öz yeterlik ölçeklerini kapsayacak şekilde iki bölümden oluşmaktadır. Araştırmada benlik saygısını ölçmek amacıyla; Rosenberg (1965) tarafından geliştirilen, Çuhadaroğlu (1986) tarafından Türkçe'ye uyarlaması yapılan 10 ifade ve tek boyuttan oluşan "Rosenberg Self-Esteem Scale (Rosenberg Genel Benlik Saygısı"” ölçeği kullanılmışıı. Öz yeterliği ölçmek için; Jerusalem ve Schwarzer (1981) tarafından geliştirilen "General Self-Efficacy (GSE) Scale (Genel Öz Yeterlik Ölçeği)", Aypay (2010) tarafından Türkçe'ye uyarlaması yapılan toplam 10 ifade ve tek boyuttan oluşan ölçek kullanılmıştır. Bilinçli farkındalığı ölçmek amacıyla; Brown ve Ryan (2003) tarafından geliştirilen "The Mindful Attention Awareness (MAAS) Scale (Bilinçli Farkındalık Ölçeği)", Özyeşil vd. (2011) tarafindan Türkçe'ye uyarlaması yapılan toplam 15 ifade ve tek boyuttan oluşan ölçek kullanılmışır. Katılımcılardan her bir ifadeyi 5’li Likert ölçeği kullanarak derecelendirmeleri istenmiştir. Buna göre " $5=K e s i n l i k l e$ Katıllyorum"; "4=Katıllyorum"; "3=Ne Katlliyorum Ne Katımıyorum"; "2=Katımıyorum"; "1=Kesinlikle Katılmıorum"u ifade etmektedir. Bu makalenin veri toplama süreci 2020 ylından önce yapılmış olması nedeniyle etik kurul izni bulunmamaktadır.

\subsection{Araştırmanın Modeli}

Araştırmanın modeli literatür çalışmasından elde edilen bilgiler doğrultusunda yapılandırılmıştır.

Bağımlı değişken çalışmanın birincil değişkenidir. Diğer değişkenlerden etkilendiği düşünülen değişkendir. Bağımsız değişken ise bağımlı değişken üzerine etkisi araştırılan değişkendir. 
Şekil 1.Araştırma Modeli

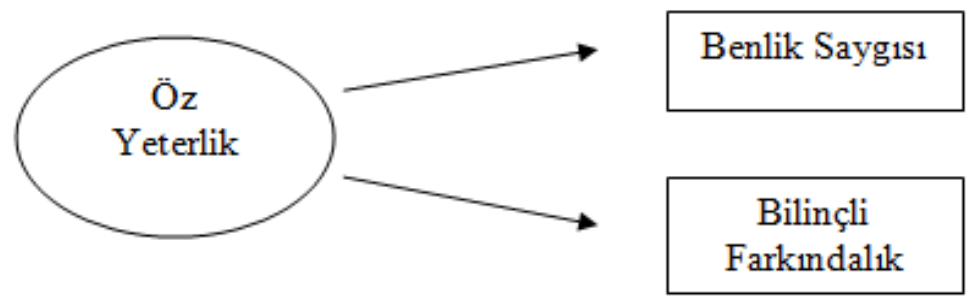

Araştırma modelinde üç tür değişken dikkate alınmış ve bu değişkenler arasındaki ilişkiler incelenmeye çalışıımıştır. Bağımlı değişken olarak Bilinçli Farkındalık ve Benlik Saygısı, bağımsız değişken olarak Öz Yeterlik ele alınmıştır. Bu bağlamda, katılımcıların öz yeterliklerinin bilinçli farkındalık ve benlik saygısı üzerindeki etkisi Şekil 1'de yer alan model üzerinden araştırılacaktır.

\section{Araştırmaya iliş̧kin Bulgular}

\subsection{Güvenirlik Analizleri}

Güvenirlik analizi ölçmede kullanılan testlerin, anketlerin ya da ölçeklerin özelliklerini ve güvenirliklerini değerlendirmek üzere geliştirilmiş bir yöntemdir.

Alfa katsayısına bağıı olarak ölçeğin güvenirliği aşağıdaki gibi yorumlanmaktadır:

$0.00 \leq \alpha<0.40$ güvenilir değildir,

$0.40 \leq \alpha<0.60$ güvenirliği düşük,

$0.60 \leq \alpha<0.80$ ölçek oldukça güvenilir,

$0.80 \leq \alpha<1.00$ ölçek yüksek derecede güvenilir bir ölçektir (Kalaycı, 2018: 403, 405).

Bilinçli farkındalık, öz yeterlik ve benlik saygısı ifade sayısı, ortalaması ve standart sapması Tablo 1'de gösterilmektedir.

Tablo 1. Bilinçli Farkındalık, Öz Yeterlik ve Benlik Saygısı Psikometrik Özellikleri

\begin{tabular}{lcccc}
\hline \hline Boyut & ifade Sayısı & Cronbach $\alpha$ & Ort. & Ss. \\
\hline Bilinçli Farkındalık & 10 & 0.735 & 2.597 & 0.533 \\
Öz Yeterlik & 10 & 0.902 & 4.001 & 0.704 \\
Benlik Saygısı & 9 & 0.790 & 3.247 & 0.374 \\
\hline
\end{tabular}

Tablo 1'de görüldüğü üzere bilinçli farkındalık Cronbach Alfa değeri 0.735 olarak bulunmuştur. Ölçek oldukça güvenilir aralığında yer almaktadır. Öz yeterlik Cronbach Alfa değeri 0.902 olarak bulunmuştur. Ölçek yüksek derecede güvenilir aralığında yer almaktadır. Benlik saygısına yapılan ilk analiz sonucunda Cronbach Alfa değeri güvenilir değil aralı̆̆ında çıkmıştır. Ölçeğin güvenirliğini 
artırmak için bir madde analizden çıkartılarak tekrar test edilmiştir. Benlik saygısı Cronbach Alfa değeri 0.790 olarak değişmiştir. Ölçeğin oldukça güvenilir aralığında yer aldığı görülmüştür.

\subsection{Normallik Analizleri}

Bağımsız değişken olan öz yeterliğin, bağımlı değişkenler olan bilinçli farkındalık ve benlik saygısı üzerindeki etkisini ölçmek için hangi tür testlerin uygun olacağına karar vermek amacıyla öncelikle bilinçli farkındalık, benlik saygısı ve öz yeterlik değişkenlerine normallik testleri uygulanmıştır. Normallik testi için veri sayısı 29 ve 29'dan fazla ise Kolmogrov-Smirnov, 29'dan az ise Shapiro-Wilk testi kullanılmaktadır. Verilerin SPSS programı ile analiz edilerek, Shapiro-Wilk veya KolmogrovSmirnov testleri için elde edilen anlamlılık (Sg. p) değeri 0.005 değerinden büyükse veriler normal dağılmış, anlamlılık (Sig. p) değeri 0.005 değerinden küçükse veriler normal dağılmamış demektir (Karagöz, 2017: 104).

$\mathrm{Bu}$ araştırmadaki $\mathrm{n}$ (Öğrenci)=125 olduğundan Kolmogrov-Smirnov testinin sonuçlarının dikkate alınması gerekmektedir. Analiz sonuçları Tablo 2'deki gibidir.

Tablo 2. Bilinçli Farkındalık, Öz Yeterlik ve Benlik Saygısı Normallik Analizi Sonucu

\begin{tabular}{lccccc}
\hline \hline Boyut & $\begin{array}{c}\text { Çarpıklık } \\
\text { (Skewness) }\end{array}$ & $\begin{array}{c}\text { Basıklık } \\
\text { (Kurtosis) }\end{array}$ & \multicolumn{3}{c}{ Kolmogrov-Smirnov } \\
& & & Statistic & Df & \multicolumn{2}{c}{ Sig. $(p)$} \\
\hline Bilinçli Farkındalık & -0.120 & -0.343 & 0.059 & 125 & 0.200 \\
Öz Yeterlik & -1.015 & 1.727 & 0.110 & 125 & 0.001 \\
Öz Yeterlik & -0.766 & 0.821 & 0.095 & 124 & 0.008 \\
Benlik Saygısı & -0.394 & 0.667 & 0.112 & 124 & 0.001 \\
Benlik Saygısı & 0.240 & 0.569 & 0.103 & 123 & 0.003 \\
\hline
\end{tabular}

Tablo 2' de görüldüğü üzere bilinçli farkındalık p değeri 0.005 'den büyük çıkmıştır.

Bu durumda bağımsız değişken olan öz yeterliğin bağımlı değişken olan bilinçli farkındalık üzerindeki etkisini ölçmek için parametrik testler kullanılmıştır. Öz yeterliğin p değeri $0.005^{\prime}$ den büyük çıkmamıştır. Bu, dağılımın normal dağıımadığının göstergesidir. Bu doğrultuda yapılması gereken öz yeterliğin normal dağılıma dönüştürülmeye çalışıımasıdır.

Uç değerler, ortalama civarında dağılan verilerden oldukça büyük veya küçük değerlerdir. Bir veri grubunda bulunan uç değerler; veri grubunun içindeki aşırı değer ya da verilerin analizlerinden elde edilen çıktılarının yorumlanmasında önemli bir etkiye sahip olan, çeşitli değişkenlerin olağandışı/aykırı kombinasyonları biçiminde olabilirler. Uç değerlerin ortaya çıkış sebepleri olarak veri sürecinde oluşan hatalar, cevaplayanın kasıtlı cevaplar vermesi, örnekleme, uygulama ve ölçme hataları, dağıııma ait yanlış varsayımda bulunulması, verilerin alındığı ana kütlenin yapısı, soruların yanlış anlaşılmasından kaynaklı hatalar sayılabilir. Uç değerleri belirleme; tek değişkenli ve çok değişkenli olmak üzere iki başlık altında incelenmektedir. Tek değişkenli uç değerler, SPSS programında bulunan outliers kullanılarak yapılabilmektedir (Karagöz, 2017: 106,110-111). 
Çalışmada kullanılan ölçek tek değişkenli olduğundan uç değer incelemesi outliers analizi ile gerçekleştirilmiştir. Dönüşüm sonrası normallik testi sonucu Tablo 2'de gösterilmiştir. p değeri 0.005 'den büyüktür. Dönüşüm işlemi veri setinin normalliğini sağladığından parametrik testler kullanılmıştır. Uç noktadaki verilerin tespit edilmesinden sonra, uç noktada bulunan 1 anket verisi analizden çıkartılarak verilerin normal dağılıma uygunluğu sağlanmıştır. 125 öğrenciden oluşan örneklem sayısı bu nedenle 124'e düşmüştür.

Benlik saygınsın p değeri 0.005 'den büyük çıkmamıştır. Bu, dağılımın normal dağımadığının göstergesidir. Bu doğrultuda yapılması gereken benlik saygısının normal dağılıma dönüştürülmeye çalışılmasıdır. Çalışmada kullanılan ölçek tek değişkenli olduğundan uç değer incelemesi outliers analizi ile gerçekleştirilmiştir. Dönüşüm sonrası normallik testi sonucu Tablo 2'de gösterilmiştir. $p$ değeri dönüşüm işlemi sonrasında hala 0.005 'den büyük çıkmamıştır. Dönüşüm işlemleri veri setinin normalliğini sağlayamadığından bağımsız değişkenin benlik saygısı üzerindeki etkisini ölçmek için parametrik olmayan (non-parametrik) testler kullanılmıştır.

\section{3. Öğrencilere iliş̧kin Demografik ve Diğer Bulgular}

Öğrencilerin demografik değişkenlere göre dağııımı aşağıda Tablo 3'de gösterilmektedir.

Tablo 3. Öğrencilere İlişkin Demografik Bulgular

\begin{tabular}{|c|c|c|c|c|c|}
\hline Değişkenler & $N$ & $\begin{array}{c}\text { Yüzde } \\
(\%)\end{array}$ & Değişkenler & $N$ & $\begin{array}{c}\text { Yüzde } \\
\text { (\%) }\end{array}$ \\
\hline Cinsiyet & \multicolumn{5}{|c|}{ Genel Not Ortalamasından } \\
\hline Kadın & 56 & 45,2 & Memnunum & 33 & 26,6 \\
\hline Erkek & 68 & 54,8 & Memnun Değilim & 91 & 73,4 \\
\hline Yaş & \multicolumn{5}{|c|}{ Okul Hayatında Kendimi } \\
\hline $18-20$ & 63 & 50,8 & Başarısız Buluyorum & 16 & 12,9 \\
\hline $21-23$ & 47 & 37,9 & Biraz Başarılı Buluyorum & 70 & 56,5 \\
\hline $24-28$ & 14 & 11,3 & Başarılı Buluyorum & 35 & 28,2 \\
\hline Sinıf & & & Çok Başarılı Buluyorum & 3 & 2,4 \\
\hline 3. Sinıf & 124 & 100.0 & \multicolumn{3}{|c|}{ Aylık Geliri Karşılama Durumu } \\
\hline Bölüm & & & Aile & 70 & 56,5 \\
\hline İşletme & 124 & 100.0 & Burs & 12 & 9,7 \\
\hline \multicolumn{3}{|c|}{ Genel Not Ortalaması } & Kredi & 33 & 26,6 \\
\hline $1.17-1.85$ arası & 38 & 30,6 & Çalışarak & 9 & 7,3 \\
\hline $1.87-2.24$ arası & 36 & 29,1 & & & \\
\hline $2.25-3.50$ arası & 50 & 40,3 & Toplam & 124 & 100.0 \\
\hline
\end{tabular}


Katıımcıların \%54.8'si erkek, \%45.2'si kadındır. Yaşları \%50.8 oranla 18-20, \%37.9 oranla 21-23 ve \%11.3 oranla 24-28 arasında dağılım göstermektedir. Tamamı üçüncü sınıf ve işletme bölümünde öğrenim gören öğrencilerin, \%40.3'lük bir kısmı 2.25-3.50 arasında not ortalamasına, \%30.6'sı 1.171.85 arasında not ortalamasına, \%29'u 1.87-2.24 arasında not ortalamasına sahiptir. Öğrencilere yöneltilen "Genel not ortalamanızdan memnun musunuz?"sorusuna \%73.4'ü "Hayır", \%26.6'sı "Evet" cevabını vermiştir. "Okul hayatınızda kendinizi nasıl buluyorsunuz?" sorusuna \%56.5'i "Biraz başarılı buluyorum", \%28.2'si "Başarılı buluyorum", \%12.9'u "Başarısız buluyorum", \%2.4'ü ise "Çok başarılı buluyorum" cevabını vermiştir. "Aylık gelirinizi nasıl karşılıyorsunuz?" sorusuna ise \%56.5’i "Aile", \%26.6'sı "KYK-Kredisi”, \%9.7'si "KYK-Bursu” ve son olarak \%7.3'ü "Çalışarak" cevabını vermiştir.

\subsection{Korelasyon Analizi}

Bilinçli farkındalık, öz yeterlik ve benlik saygısı arasındaki ilişkiyi ortaya koyabilmek amacıyla korelasyon analizi yapılmıştır. Öğrencilerin bilinçli farkındalık, öz yeterlik ve benlik saygıları arasında bir ilişki olup olmadığı Spearman Korelasyon Analizi ile incelenmiştir. Korelasyon analizi yapılırken Spearman Korelasyon analizinin kullanmasının nedeni, ele alınan değişkenlerden bilinçli farkındalık ve öz yeterlik normal dağılıma uygunluk gösterirken, benlik saygısı normal dağılıma uygunluk göstermemiştir. Değişkenlerin dağılımının normallikten uzak olduğu durumlarda Spearman sıra koleksiyonu kullanılmaktadır (Kalaycı, 2018: 117).

Tablo 4. Korelasyon Analizi

\begin{tabular}{|c|c|c|c|}
\hline & Öz Yeterlik & Bilinçli Farkındalık & Benlik Saygısı \\
\hline Öz Yeterlik & 1 & & \\
\hline Bilinçli & $r=-0,342 * *$ & & \\
\hline Farkındalık & $p=0,000$ & & \\
\hline Benlik Saygısı & $\begin{array}{c}r=0,346^{* *} \\
p=0,000\end{array}$ & $\begin{array}{l}r=-0,049 \\
p=0,590\end{array}$ & 1 \\
\hline$n=124$ için & $\begin{array}{l}\text { ** İlişki } 0.01 \text { düzeyir } \\
\text { * } \quad \text { iliş̧ki } 0.05 \text { düzeyin }\end{array}$ & $\begin{array}{l}\text { de anlamlı (2-tailed) } \\
\text { de anlamlı (2-tailed) }\end{array}$ & \\
\hline
\end{tabular}

Bilinçli farkındalık, öz yeterlik ve benlik saygısı boyutları arasındaki ilişki Tablo 4'de gösterilmiştir. Korelasyon analizi sonuçlarına göre öz yeterlik ile bilinçli farkındalık arasında $(-0.342)$ zayıf ve negatif bir korelasyon olduğu görülmektedir. Bu durumda bilinçli farkındalık arttıkça öz yeterlik azalmaktadır. Öz yeterlik ile benlik saygısı arasında (0.346) zayıf ve pozitif bir korelasyon olduğu görülmektedir. Bu durumda benlik saygısı arttıkça öz yeterlik de artmaktadır. 


\subsection{Regresyon Analizi}

Regresyon analizi; bir veya daha fazla bağımsız değişkenin değerlerine dayanarak, bağımlı değişkenin ortalama değerlerini tahmin eder. Başka bir deyişle regresyon, bağımsız değişkenin değerlerine dayanarak, bağımlı değişkenin ortalama değerlerinin elde edilebildiği denklemi verir (Karagöz, 2017: 362).

Öz yeterliğin bilinçli farkındalık ve benlik saygısı üzerindeki etkisini ölçmek için Linear Regresyon analizi yapılmıştır. Öz yeterliğin bilinçli farkındalık ve benlik saygısı üzerindeki etkisini ölçen analiz sonuçları Tablo 5'de gösterilmiştir.

Tablo 5. Regresyon Analizi Sonuçları

\begin{tabular}{lccc}
\hline \hline & \multicolumn{4}{c}{$\begin{array}{c}\text { Bağımlı Değişken } \\
\text { Bilinçli Farkındalık }\end{array}$} \\
\hline Bağımsız Değişken & $\beta$ & $\mathrm{t}$ & Sig (p) \\
\hline Öz Yeterlik & $-0,273$ & $-4,021$ & 0,000 \\
Sabit (Constant) & 3,689 & 13,317 & 0,000 \\
\hline & $\mathrm{F}=16,168$ & & \\
& $\mathrm{R}^{2}=0,342$ & &
\end{tabular}

Adj. $R^{2}=0,110$

\begin{tabular}{lccc} 
& \multicolumn{3}{c}{$\begin{array}{c}\text { Bağımlı Değişken } \\
\text { Benlik Saygısı }\end{array}$} \\
\hline Bağımsız Değişken & $\beta$ & $\mathrm{t}$ & Sig $(\mathrm{p})$ \\
\hline Öz Yeterlik & 0,208 & 4,073 & 0,000 \\
Sabit (Constant) & 2,552 & 12,254 & 0,000 \\
\hline \multicolumn{4}{c}{$\mathrm{F}=16,593$} \\
& $\mathrm{R}^{2}=0,346$ & & \\
& Adj. $\mathrm{R}^{2}=0,113$ & & \\
\hline
\end{tabular}

Öz yeterlik boyutunun bilinçli farkındalık üzerindeki etkisini açıklamak maksadıyla oluşturulan regresyon modelinin $\mathrm{F}$ değeri 16.168 , anlamlılık düzeyi ise $\mathrm{p}<0.001$ 'dir. Öz yeterlik boyutunun benlik saygısı üzerindeki etkisini ölçen regresyon analizinde $F$ değeri 16.593 ve anlamlılık düzeyi p<0.001'dir. Öz yeterlik boyutu bilinçli farkındalık ve benlik saygısını \%34 oranında açıklamaktadır. Diğer bir ifade ile öz yeterliğin \%34'ü bilinçli farkındalık ve benlik saygısına bağlıdır. Analiz sonuçlarına göre bilinçli farkındalık $(\beta=-0.273, p<0.001)$ öz yeterlik düzeyini azaltmakta ve benlik saygısı ( $\beta=-$ 0.208 , p<0.001) öz yeterlik düzeyini artırmaktadır. Bilinçli farkındalıktaki bir birimlik artış öz yeterliği -0.273 birim azaltmakta, benlik saygısındaki bir birimlik artış öz yeterliği 0.208 birim artırmaktadır. Öz yeterliğin bilinçli farkındalık üzerinde anlamlı ve negatif, benlik saygısı üzerinde anlamlı ve pozitif bir etkisinin olduğu saptanmıştır. Sonuç itibariyle belirlenen hipotezlerden $\mathrm{H}_{1}$ reddedilirken, $\mathrm{H}_{2}$ 'nin ise kabul edildiği görülmüştür. 


\section{Sonuç}

Öz yeterlilik, bireyin bir işe başlamadan önce onu başarabileceğine dair oluşturduğu inanç ve kendine olan güvenidir. Kişi bu inanç ve güvene göre yapacaklarına ve hatta yapmak isteyeceklerine karar vermektedir (Bandura, 1994: 8).

Benlik, bireyin kendisinde var olan bütün özelliklerinin bilincinde olması, bunlar ile elde edebileceği maddi ve manevi başarılara inanmasını temsil etmektedir. Rogers (1959) tarafından geliştirilen bu kavrama göre; kişiler durumlar karşısında bir takım davranışlar sergilemektedirler. Birey, kendi benliğine uygun olmayan bir davranışı yaparken zorlanmakta, hatta yaşamını da benliğine göre düzenlemektedir (Yiğit, 2018: 59).

Kişinin benlik algısı kendi öz yeterlilik algısı üzerinde de şüphesiz etki sahibidir. Benlik olgusu gelişmiş bir birey, hangi konularda başarılı olacağının da bilincinde olmaktadır. Dolayısıyla benlik algısını geliştiren unsurların öz yeterlilik algısını da etkilemesi beklenmektedir. Bu durumun tersi biçimde herhangi bir açıdan öz yeterlilik algısını güçlendiren bir bireyin benlik algısı da güçlenecektir (Bandura, 1997: 80).

Bilinçli farkındalık, bilerek ve sürekli, var olunan an içinde, yargılamadan dikkat verilerek gerçekleştirilmektedir. Bilinçli farkındalıkta sistematik şekilde enerji ve dikkat düzenlemesi yapılmaktadır ki bu sayede deneyimlerinin niteliklerini etkileme ve dönüştürmesi mümkün olabilmektedir. Bu dönüşümün amacı ise insanlığın, diğerleriyle ve dünya ile olan ilişkinin, bütüncül biçimde farkına varmaktır (Yılmam, 2019: 64).

Öz yeterlik inancın bir şeklidir. İnanç ve öz yeterliğin her ikisi de daha iyi olmak için çabalamayı sürdürdügümüzde daha kolay bir şekilde gerçekleşir. Bilinçli farkındalık bireye dikkat, enerji ve hatırlama olgularını aşılayarak bireyi öz yeterliğe götürür. Bilinçli farkındalığı yüksek kişilerin öz yeterlikleri üzerindeki olumlu etkisi sonucu kişiler, kendilerine karşı da inançla yaklaşma eğiliminde olacaklardır.

Bu çalışmada, öz yeterliğin benlik saygısı ve bilinçli farkındalık kavramlarına olan ilişkileri kuramsal olarak tartışılmış ve üniversite öğrencilerinden seçilen bir örneklemde yapılan bir araştırma ile öğrenciler üzerine öz yeterlik duygusunun açıklanmasında, benlik saygısı ve bilinçli farkındalık etkilerinin ortaya çıkarılması amaçlanmıştır.

Araştırmanın bulgularını ise şu şekilde özetlemek mümkündür;

Katıımcıların büyük çoğunluğu erkek öğrencilerden oluşmaktadır. Yaş dağılımı 18-20 arası olan katılımcılar, işletme bölümü örgütsel davranış dersini alan ve üçüncü sınıfta öğrenim gören öğrencilerdir. Öğrencilerin yarısına yaklaşık bir kısmı 2.25-3.50 aralığında not ortalamasına sahiptir. Öğrencilere yöneltilen “Genel not ortalamanızdan memnun musunuz?”'sorusuna büyük çoğunluğu "Hayır" cevabını vermiştir. "Okul hayatınızda kendinizi nasıl buluyorsunuz?” sorusuna öğrencilerin yarısı "Biraz başarılı buluyorum" cevabını vermiştir. Öğrencilerin yarısından fazlası ise ailesinden gelen bütçe ile geçimini sağlamaktadır. 
Yapılan korelasyon analizi sonucunda öz yeterlik ile bilinçli farkındalık arasında negatif bir korelasyon olduğu tespit edilmiştir. Öz yeterlik ile benlik saygısı arasında ise pozitif bir korelasyon olduğu saptanmıştır. Bu durumda bilinçli farkındalık arttıkça öz yeterliğin azaldığı, benlik saygısı arttıkça öz yeterliğin de arttığı yorumu yapılabilir. Öz yeterliğin bilinçli farkındalık ve benlik saygısı üzerindeki etkisini tespit etmek yapılan regresyon analiz sonuçlarına göre; bilinçli farkındalık öz yeterlik düzeyini azaltırken, benlik saygısı öz yeterlik düzeyini artırmaktadır. Bu bağlamda, öz yeterliğin bilinçli farkındalık üzerinde anlamlı ve negatif, benlik saygısı üzerinde anlamlı ve pozitif bir etkisinin olduğu görülmüştür.

Yapılan analizler sonucunda öz yeterlik algısı ile benlik saygısı arasında anlamlı ve pozitif bir ilişki bulunmuştur. Bu bulguya göre benlik saygısı düzeyi arttıkça öz yeterliğin de artması beklenmektedir. Çalışmanın bu bulgusu ile tutarlı olarak, alan yazında Yiğit'in (2018) çalışmasında öz yeterlik ve benlik saygısı arasında düşük düzeyli fakat istatistiki açıdan anlamlı bir ilişki olduğu bulunmuştur. Altun ve Yazıcı'nın (2012) öğrenci örnekleminden oluşmuş çalışmasında, öz yeterlik ile benlik saygısı arasında pozitif bir ilişki olduğu görülmüştür. Buluş ve Öztürk Samur'un (2017) ebeveyn örnekleminde benlik saygısı ve öz yeterlik arasında pozitif bir ilişki olduğu saptanmıştır. D’Amico ve Cardaci'nin (2003) araştırma bulgularına göre, öz yeterlik ve benlik saygısının ilişkide olduğu sunulmuştur. Diseth vd. (2014) ortaöğretim öğrencilerinin öz yeterlik ve benlik saygısı düzeylerinin istatistiksel olarak anlamlı ancak düşük pozitif korelasyon gösterdiği sonucuna varmıştır.

Alan yazındaki birçok çalışma öz yeterlik ve bilinçli farkındalık arasında pozitif ve anlamlı bir ilişki olduğu yönündedir. Atalay vd.'nin (2017b) ortaöğretim öğrencilerinin oluşturduğu bir çalışmada, bilinçli farkındalık düzeyi arttıkça öz yeterlik düzeyinin hafif de olsa arttığı görülmüştür. Bakioğlu’nun (2017) çalışmasında katılımcıların bilinçli farkındalıklarının kültüre duyarlı psikolojik danışma yeterlikleri aracılığıyla öz yeterliklerini yordamasında dolaylı etkilerinin anlamlı olduğu tespit edilmiştir. Brown ve Ryan'ın (2003) çalışmasında öğrencilerin bilinçli farkındalık düzeyleri ile öz yeterlik arasında pozitif bir ilişki olduğu yönündedir. Luberto vd.'nin (2014) çalışmasında bilinçli farkındalık ile hareket etmenin öz yeterlik ile ilişkili olduğunu göstermiştir. Fallah (2016) bilinçli farkındalığı yüksek olanların öz yeterliklerinin yüksek olduğunu ve dil kaygılarının düşük seviyede olduğunu tespit etmiştir. Araştırmada etkisi incelenen öz yeterliğin bilinçli farkındalık ile negatif yönde anlamlı bir ilişkisi bulunmuştur. Bu bulgular alan yazındaki araştırmalar ile benzerlik göstermemektedir. Yapılan araştırmada bu konudaki çalışmalardan farklı sonuçlar elde edilmesinin nedeni olarak, katıım gösteren öğrencilerin bilinçli farkındalık düzeylerinin düşük çıkması, seçilen örneklem gurubunun sosyal ve kültürel özelliklerinin sonuçta etkili olduğu düşünülmektedir. Literatürde de öz yeterlik ile bilinçli farkındalık ve benlik saygısı arasında çok net ilişkiler kurabilen çalışmalara rastlanmamış olması da elde edilen verilerle, öz yeterliğin etkilerinin bilinçli farkındalık düzeyini düşüreceği gibi belirgin bir önermede bulunmak söz konusu değildir. Ancak, bu sonuçlar araştırmanın yapıldığı örneklemle bağlantılı olarak düşünülmeli, bütün öğrenciler için genellenmemelidir.

Örgütsel davranışın amaçları arasında insan davranışlarını anlamak ve örgüt içindeki çalışanı daha etkin ve başarılı kılmak, bireylerin bilişsel, devinimsel ve duygusal davranışlarını, örgüte uyumu 
sağlamalarının yollarını, takım içindeki çalışmalarını, bireylerin davranışlarını etkileyen unsurları araştırmak bulunmaktadır. Bireyler örgütün olmazsa olmaz unsurlarıdır. Bireyin davranış ve yaklaşımları da örgütün yararına olacak ana kaynak olarak nitelendirilmekte, örgütün geçmişini ve geleceğini şekillendirerek amaçlarına ulaşması için katkı sunmaktadır. Diğer bir deyişle, bireyler örgüt için veya örgüt adına atılan her adımın kilit karakteri olduklarından bir örgütün en faydalandığı unsurlar olacaklardır (Güven, 2017).

Bu bağlamda, örgütsel davranış dersini alan öğrencilere de bu yönde eğitimler verilmekte ve öğrencilerin davranış ve tutumlarının pozitif anlamda gelişmesi ve değişmesi amaçlanmaktadır. Tüm bunlar göz önüne alındığında, elde edilen bulgular ışığında öz yeterlik, benlik saygısı ve bilinçli farkındalık bireysel ve örgütsel açıdan sıkıkla karşılaşılabilecek kavramlar olup hem bireysel hem de örgüt düzeyinde üzerinde durulması gereken önemli konular olabilmektedir. Erken dönemlerde gerekli özenin gösterilmesi ve öğrencilere bu davranış düzeyleri açısından eğitimlerin verilmesi, onların gerek şahsi gerekse iş hayatlarında olumlu bir biçimde ilerlemesine kaynaklık edebilecektir.

Bulguların genelleştirilmesi ve araştırmacıların aynı konulardaki araştırmalarını daha geniş kapsamlı ve çok yönlü ele alabilmesi için, araştırma farklı bölümlerde öğrenim gören öğrenciler üzerinde yapılabilir ve daha geniş bir örneklemde uygulanabilir. Bu sayede farklı fakültelerde ve bölümlerde öğrenim gören öğrenci grupları ve örneklemlerle yürütülecek çalışmalar, elde edilebilecek sonuçları artırabilecektir. Ele alınan değişkenlerin etkisinin karşılaştırılabilmesi için daha sonraki araştırmaların benzer özellikler göstermeyen örneklemlerde yapılması daha iyi olabilir. Diğer yandan öğrenci örneklemi bazında yapıımış olan bu çalışmanın, özel sektörde veya kamu sektöründe yapılabilecek benzer çalışmalar ile farklı bulgular elde edilmesi sağlanabilir. Benzer çalışmalar daha büyük ve farklı özellikteki çalışma grupları ile yürütülebilir.

Öz yeterlik seviyesi yüksek olan kişiler, belirli bir hedefe ulaşmada ya da sorunlarıyla başa çıkma çabalarında kararlı ve istikrarlı olmaktadır. Yüksek yeterlik inancı, bireyde kişisel doyumu ve başarıyı arttırmaktadır. Kendini olduğu gibi gören bireylerin, benlik saygıları yüksektir. Gördüğü gibi kabullenen ve kendine güvenen kişiler, kendini değerli ve saygıya değer hisseder ve hayattaki sorunlarla başa çıkabileceğine inanır. Mutlu, rahat ve uyanık olan bireylerin bilinçli farkındalıkları yüksek olmaktadır. Farkındalığı yüksek olan kişiler, önemli problemlerle karşılaştıklarında probleme odaklanmak yerine, o sorunun farkına varıp kendilerini olumsuz yarglamamakta ve kendilerini anlamayı tercih etmektedirler. Görüldügü üzere öz yeterlik, benlik saygısı ve bilinçli farkındalık düzeyleri yüksek olan bireyler başarılı, özgüvenli ve huzurlu olmaktadır. Bu duygulara sahip bireylerin gerek sosyal gerek kişisel gerekse eğitim hayatında daha iyi yerlerde olması beklenmektedir.

Bireylerin bilinçli farkındalık, öz yeterlik ve benlik saygısı düzeylerini geliştirmek için bu konularla ilgili eğitimler çocukluk çağından itibaren önemsenmeli ve okullarda ve üniversitelerde de bu yönde eğitimler verilmelidir. Kişilere bilinçli farkındalık yönünde eğitimler verilerek hoşlanmadıkları özelliklerini bilinçli ve açık bir şekilde kabul etmeleri ve içinde bulundukları durumlara olumlu yaklaşmaları sağlanabilir. Verilecek öz yeterlik eğitimleri ile kendilerine olan inanç duygularını 
güçlendirerek, yapmak istedikleri herhangi bir şeyi başarabilme düşüncesi aşılanabilir. Son olarak ise benlik saygısı eğitimleri verilerek, sahip olduğu yetenek ve kapasitesinin farkına varması sağlanabilir.

\section{Araştırma ve Yayın Etiği Beyanı}

Bu makalenin veri toplama süreci 2020 yılından önce yapılmış olması nedeniyle etik kurul izni bulunmamaktadır.

\section{Yazarların Makaleye Katkı Oranları}

Bu çalışma iki yazarı ıir makale olduğundan yazarların katkı oranı birbirine eşittir.

\section{Çıkar Beyanı}

Çıkar Beyanı: Yok.

\section{Kaynaklar}

Acat, M. B., Özyurt, O. ve Karadağ, E. (2011), İlköğretim Okul Müdürlerinin Mevzuat Görevleri Öz Yeterlilik Düzeylerinin Değerlendirilmesi, NWSA: Education Sciences, 6(1), 605-620.

Altun, F. ve Yazıcı, H. (2012), Üstün Yetenekli Öğrencilerin Benlik Kavramları ve Akademik ÖzYeterlik İnançları: Karşılaştırmalı Bir Çalışma, Mehmet Akif Ersoy Üniversitesi Eğitim Fakültesi Dergisi, 12(23), 319-334.

Aşık, M. (2019), Üniversite Öğrencilerinin Öz Yeterlik Düzeylerinin Öz Anlayış Ve Ebeveyn Kabul-Reddine illişkin Algıları Çerçevesinde İncelenmesi, Eskişehir Anadolu Üniversitesi Eğitim Bilimleri Enstitüsü, Rehberlik ve Psikolojik Danışmanlık Programı Eğitim Bilimleri Anabilim Dalı, Yüksek Lisans Tezi, 1-91.

Atalay, Z., Aydın, U., Bulgan, G., Taylan, R. D. ve Özgülük, S. B. (2017a), Bilinçli-Farkındalık Temelli Öz Yeterlik Ölçeği-Yenilenmiş (BFÖÖ-Y): Türkiye Uyarlama Çalışması, Elementary Education Online, 16(4), 1803-1815.

Atalay, Z., , U., Bulgan, G., Taylan, R. D. ve Özgülük, S. B. (2017b), Bilinçli-Farkındalık (Mindfulness) Temelli Psiko-Eğitim Programının Öğrencilerin Matematik Kaygısı, Tutumları Ve Öz Yeterlikleri Üzerindeki Etkisi, TÜBiTAK Projesi, Program Kodu: 1001, Proje No: 115K450, İstanbul.

Aypay, A. (2010), Genel Öz Yeterlik Ölçeği'nin (GÖYÖ) Türkçe’ye Uyarlama Çalışması, Inönü Üniversitesi Eğitim Fakültesi Dergisi, 11(2), 113-131.

Bakioğlu, F. (2017), Psikolojik Danışman Adaylarının Özyeterlikleri ille Kültüre Duyarlılıkları, Cinsiyet Rolleri ve Bilinçli Farkındalıkları Arasındaki İlişkilerin İncelenmesi, Eskişehir Anadolu Üniversitesi Eğitim Bilimleri Enstitüsü, Doktora Tezi, 1-124. 
Bandura, A. (1994), Self-Efficacy, In V. S. Ramachaudran (Ed.), Encyclopedia Of Human Behavior, (4), 71-81.

Bandura, A. (1997), Self-Efficacy in Changing Societies, Cambridge: Cambridge University Press, Journal of Developmental \& Behavioral Pediatrics,18(4), 280-334.

Basım, N., Korkmazyürek, H. ve Tokat, A. O. (2008), Çalışanların Öz Yeterlik Algılamasının Yenilikçilik ve Risk Alma Üzerine Etkisi: Kamu Sektöründe Bir Araştırma, Selçuk Üniversitesi Sosyal Bilimler Enstitüsü Dergisi, 19, 101-119.

Brown, K. W. ve Ryan, R. M. (2003), The Benefits of Being Present: Mindfulness and Its Role in Psychological Well-Being, Journal of Personality and Social Psychology, 84(4), 822848.

Buluş, M. ve Öztürk Samur, A. (2017), Beş-Altı Yaş Çocuklarının Sosyal Duygusal Uyumunu Yordamada Ebeveyn Benlik Saygısı, Temel İhtiyaçları ve Öz Yeterliğin Rolü, PAU Eğitim Fakültesi Dergisi, (41), 105-119.

Cengiz, R., Serdar, E. ve Donuk, B. (2016), Üniversite Öğrencilerinin Bilinçli Farkındalık ve Girişimcilik Düzeylerinin Incelenmesi, International Journal of Social Sciences and Education Research, 2(4), 1321-1328.

Çelik, D. A. ve Çetin, F. (2014), The Role Mindfulness and Self-Consciouness on Interpersonal Conflict Rresolution Approaches, Research Journal of Business and Management, 1(1), 29-38.

Çevik Demir, Ş. (2013), Ergenlerde Benlik Saygısı Ve Dini Başa Çıkma, Uludağ Üniversitesi Sosyal Bilimler Enstitüsü Felsefe Ve Din Bilimleri Anabilim Dalı Din Psikolojisi Bilim Dalı, Doktora Tezi, 1-235.

Çuhadaroğlu, F. (1986), Adolesanlarda Benlik Saygısı, Uzmanlık Tezi, Hacettepe Üniversitesi Tıp Fakültesi, 1-50.

D’amico, A., ve Cardacı, M. (2003), Relations among Perceived Self-Efficacy, Self-Esteem, and School Achievement, Sage Journals, 92(3).

Demir, T. (2013), İlköğretim Öğrencilerinin Yaratıcı Yazma Becerileri İle Yazma Özyeterlik Algısı İlişkisi Üzerine Bir Çalışma, Uluslararası Türkçe Edebiyat Kültür Eğitim Dergisi, 2(1), 84-114.

Deniz M. E., ve Sümer, A. S. (2010), Farklı Özanlayış Düzeylerine Sahip Üniversite Öğrencilerinde Depresyon, Anksiyete ve Stresin Değerlendirilmesi, Eğitim ve Bilim Dergisi, 35(158), 116-127.

Deniz, M. E., Erus, S. M. ve Büyükcebeci, A. (2017), Bilinçli Farkındalık İle Psikolojik İyi Oluş illişkisinde Duygusal Zekanın Aracılık Rolü, Türk Psikolojik Danışma ve Rehberlik Dergisi, 7(47), 17-31. 
Diseth, A., Meland, E. ve Breidablik, H. J. (2014), Self-Beliefs Among Students: Grade Level And Gender Differences In Self-Esteem, Self-Efficacy And Implicit Theories Of Intelligence, Learning and Individual Differences, 35, 1-8.

Erbil, N. ve Bostan. Ö. (2004), Ebe ve Hemşirelerde İşdoyumu, Benlik Saygısı ve Etkileyen Faktörler, Atatürk Üniversitesi Hemşirelik Yüksekokulu Dergisi, 7(3), 56-66.

Fallah, N. (2016), Mindfulness, Coping Self-Efficacy And Foreign Language Anxiety: A Mediation Analysis, Journal Educational Psychology, 6(37), 745-756.

Germer, C. K. (2004), What Is Mindfulness?, Insight Journal, Fall 2004, 24-29.

Germer, C. K. (2005), Mindfulness What Is It? What Does It Matter?, Mindfulness And Psychotherapy New York, NY, US: Guilford Press, 3-27.

Güven, E. (2017), Örgütsel Davranış Konuları; Çalışanlar ve Örgüt Açısından Önemi, 24 Mayıs 2020 tarihinde https://engingvn.wordpress.com/2017/12/12/orgutsel-davraniskonulari-calisanlar-ve-orgut-acisindan-onemi/ adresinden alındı.

Hanh, T. N. (1987), The Miracle Of Mindfulness: An Introduction To The Practice Of Meditation, Boston: Beacon Press.

Hanley, A. W., Palejwala, M. H., Hanley, R. T., Canto, A. I. ve Garland, E. L. (2015), A Failure In Mind: Dispositional Mindfulness And Positive Reappraisal As Predictors Of Academic Self-Efficacy Following Failure, Personality and Individual Differences, 86, 332-337.

Joo, Y. J., Bong, M. ve Choi, H. (2000), Self-Efficacy for Self-Regulated Learning, Academic SelfEfficacy, and Internet Self-Efficacy in Web-Based Instruction, Educational Technology Research and Development, 48, 5-17.

Kahriman, i. (2005), Karadeniz Teknik Üniversitesi Trabzon Sağlık Yüksekokulu Öğrencilerinin Benlik Saygıları ve Atılganlık Düzeylerinin Bazı Değişkenler Açısından İncelenmesi, Cumhuriyet Üniversitesi Hemşirelik Yüksekokulu Dergisi, 9(1), 24-32.

Kalaycı, Ş. (2018), SPSS Uygulamalı Çok Değişkenli İstatistik Teknikleri, Ankara: Dinamik Akademi Yayıncılık.

Karagöz, Y. (2017), SPSS ve AMOS Uygulamalı Bilimsel Araştırma Yöntemleri ve Yayın Etiği, Sivas: Nobel Akademik Yayıncılık.

Lawrence, D. (2000), Building self-esteem with adult learners, (First edition), London: Paul Chapman Publishing.

Leary, M. R., Tambor, E. S., Terdal, S. K. ve Downs, D. L. (1995). Self-Esteem as an Interpersonal Monitor: The Sociometer Hypothesis, Journal ol"Personality and Social Psychology, 68(3), 518-530. 
Long, B. H. (1986), Parental Discord Vs. Family Structure: Effects Or Diverce On The SelfEsteem Of Daughters, Journal Of Youth And Adolescence,1(15), 19-27.

Luberto, C. M., Cotton, S., Mcleish, A. C., Mingione, C. J. ve O'bryan, E. M. (2014), Mindfulness Skills and Emotion Regulation: The Mediating Role of Coping SelfEfficacy, SpringerLink, (5), 373-380.

Maşrabacı, T. S. (1994), Hacettepe Üniversitesi Birinci Sınıf Öğrencilerinin Benlik Saygısı Düzeylerinin Bazı Değişkenlere Göre İncelenmesi, Hacettepe Üniversitesi Sosyal Bilimler Enstitüsü, (Yayınlanmamış Doktora Tezi).

Mckay, M. ve Patrick, F. (2000), Self-Esteem, New Harbinger Publications, U.S.A.

Nebioğulları, B. (2019), Çalışan/Çalışmayan Annelerin Ebeveynlik Özyeterlilik Algıları İle 1113 Yaş Çocuklarının Algıladığı Anne Tutumu ve Benlik Saygısı Arasındaki İlişki, Maltepe Üniversitesi Sosyal Bilimler Enstitüsü Psikolojik Anabilim Dalı, Yüksek Lisans Tezi, 1-74.

Özkan, Ö., Karataş, H. ve Ergin, A. (2018), i̇lkokul Ögrencilerinin Bilinçli Farkındalık Temelli Öz-Yeterlik Düzeylerinin İncelenmesi, Akdeniz Eğitim Araştırmaları Dergisi, 12(26), 503-525.

Özyeşil, Z., Arslan, C., Kesici, Ş. ve Deniz, M. E. (2011), Bilinçli Farkındalık Ölçeği'ni Türkçeye Uyarlama Çalışması, Eğitim ve Bilim, 36(60), 225-235.

Palmer, A. ve Rodger, S. (2009), Mindfulness, Stress, and Coping Among University Students, Canadian Journal of Counselling, 43(3), 198-212.

Pope, A. W., Mchale, S. M. ve Craighead, W. E. (1988), Self-Esteem Enhancement With Children And Adolescents, (First Edition), Boston: Psychology Practitioner Guidebook Series.

Rasmussen, M. K., ve Pidgeon, A. M. (2011), The Direct and Indirect Benefits of Dispositional Mindfulness on Self-Esteem and Social Anxiety, Anxiety, Stress \& Coping, 24(2), 227-233.

Rice, V., Boykin, G., Jeter, A. ve Villarreal, J. (2013), The Relationship Between Mindfulness and Resiliency Among Active Duty Service Members and Military Veterans, In Proceedings of the Human Factors and Ergonomics Society Annual Meeting, 5(1), 1387-1391.

Rogers, C.R. (1951), Client-Centered Therapy, Boston: Houghton Mifflin Company.

Robbins, S. P. Ve Judge, T. A. (2015), Organizational Behavior (Örgütsel Davranış), Çeviri Editörü: Prof. Dr. İnci Erdem, Ankara: Nobel Yayıncılık. 
Rogers, C. R. (1959), A Theory Of Therapy, Personality, And Interpersonal Relationships, As Developed In The Client-Centered Framework. In S. Koch (Ed.), Psychology: A Study Of A Science, New York: McGraw-Hill,3, 184-256.

Rosenberg, M. (1965), Society And The Adolescent: Self-Image, Princeton: Princeton University Press.

Schutte, N.S. ve Malouff, J.M. (2011), Emotional Intelligence Mediates The Relationship Between Mindfulness and Subjective Well-Being, Personality and Individual Differences, 50, 1116-1119.

Schwarzer, R. (1994), Optimism, Vulnerability, And Self-Beliefs As Health-Related Cognitions: A Systematic Overview, Psychology \& Health, 9(3), 161-180.

Siegel, R. D., Germer, C. K. ve Olendzki, A. (2009), Mindfulness: What Is It? Where Did It Come From?, Clinical Handbook of Mindfulness, 17-35.

Singh, B. ve Udainiya, R. (2009), Self-Efficacy And Well-Being Of Adolescents, Journal of the Indian Academy of Applied Psychology, 35(2), 227-232.

Soğukpınar, E. (2014), Rehber Öğretmenlerin Benlik Saygısı İle Mesleki Benlik Saygısı Düzeylerinin Çeşitli Değişkenler Açısından İncelenmesi, Inönü Üniversitesi Eğitim Bilimleri Enstitüsü Eğitim Bilimleri Ana Bilim Dalı Rehberlik Ve Psikolojik Danışmanlık Bilim Dalı, Yüksek Lisans Tezi, 1-109.

Sung-Ja, W. (2006), The Relationship between Clinical Stress, Self-Efficacy, and Self-Esteem of Nursing College Students, The Journal of Korean Academic Society of Nursing Education, 12(2), 205-213.

Şahin, F. (1994), Yetiştirme Yurtlarında Kalan Gençlerin Benlik Saygıları Üzerine Bir Inceleme, Hacettepe Üniversitesi Sosyal Bilimler Enstitüsü, (Yayınlanmamış Yüksek Lisans Tezi).

Tang, M., Addison, K. D., Bryant, D.L., Norman, R., O'connell, W., Joseph, A. ve Sicking S. (2004), Factors That Influence Self-Efficacy of Counselling Students: An Exploratory Study, Counselor Education \&Supervision, 44(1), 70-80.

Türedi, E. (2015), Özyeterlik, Benlik Saygısı ve Atılganlık Düzeyi iliş̧isi-Cinsiyet Ve Deneyim Süresi Açısından Resmi Okul Ve Özel Okul Öğretmenleri Üzerine Bir Araştırma-, Toros Üniversitesi SosyalBilimler Enstitüsü Psikoloji Ana Bilim Dalı, Yüksek Lisans Tezi, 1-58.

Ünlü, S. (2014), Ortaokul Öğrencilerinin Türkçe Dersine Yönelik Tutumları Ve Öz Yeterlikleri Arasındaki İlişki, Çanakkale Onsekiz Mart Üniversitesi Eğitim Bilimleri Enstitüsü.

Vardarlı, G. (2005), İlköğretim II. Kademe Öğrencilerinin Genel Özyeterlik Düzeylerinin Yordanması, Ege Üniversitesi Sosyal Bilimler Enstitüsü Rehberlik ve Psikolojik Danışmanlık Bilim Dalı, Yüksek Lisans Tezi, 1-162. 
Yelkenci, Y. (2019), Aikido Yapan Ve Yapmayan Üniversite Öğrencilerinin Bilinçli Farkındalıkları, Kaygı Düzeyleri Ve Psikolojik Dayanıklılıklarının İncelenmesi, Istanbul Üniversitesi, Cerrahpaşa Lisansüstü Eğitim Enstitüsü, Yüksek Lisans Tezi, 1-126.

Yıldız, M. ve Çapar, B. (2010), Orta Öğretim Öğrencilerinde Benlik Saygısı İle Dindarlık Arasındaki İlişkinin İncelenmesi, Dinbilimleri Akademik Araştırma Dergisi, 10(1), 103131.

Yılmam, B. (2019), Bilinçli Farkındalık Ve Öz-Duyarlılığın Öznel İyi Oluş Üzerindeki Etkisi, Üsküdar Üniversitesi Sosyal Bilimler Enstitüsü Klinik Psikoloji Anabilim Dalı, Yüksek Lisans Tezi, 1-98.

Yiğit, M. C. (2018), Bireylerde Benlik Saygısı Ve Cinsel Özyeterlilik Illişkisinde Bilişsel Çarpıtmaların Rolü, Üsküdar Üniversitesi Sosyal Bilimler Enstitüsü Klinik Psikoloji Anabilim Dalı, Yüksek Lisans Tezi, 1-90. 